\title{
The Scope of the CISG Provisions on Damages
}

\author{
INGEBORG SCHWENZER" AND PASCAL HACHEM**
}

\section{GENERAL}

In the same way as under domestic laws, questions of damages have been among the most discussed issues under the Convention during the last ro years. ${ }^{x}$ Recently, the Advisory Council on the CISG (CISG-AC) published a special opinion on the calculation of damages under Article 74 CISG. ${ }^{2}$ Why are damages such a debated issue? The history of Article 74 CISG can be traced back to its predecessor, Article 82 of the Uniform Law of International Sales (ULIS). Both during the preparation of the CISG and at the Vienna Conference, there were hardly any discussions about the damages provisions. The wording of Article 82 ULIS remained practically unchanged. ${ }^{3}$

What guidelines can be derived from the wording of Article 74 CISG? As Honnold has described it, the standard established by Article 74 is brief

" Dr. iur. (Freiburg i. Br.), LL.M. (UC Berkeley), Professor of Private Law, University of Basel, Switzerland.

** Ref. (Freiburg i. Br.), Research and Teaching Assistant, University of Basel, Switzerland. 1 See JY Gotanda, 'Awarding Damages under the United Nations Convention on the International Sale of Goods: a Matter of Interpretation' (2005) 37 Georgetown Journal of International Law 95; D Saidov, 'Damages: The Need for Uniformity' (2006) 25 Journal of Law and Commerce 393 (hereinafter 'Damages'); D Saidov, 'Standards of Proving Loss and Determining the Amount of Damages' (2006) 22 Journal of Contract Law I (hereinafter 'Standards'); MW Brölsch, Schadensersatz und CISG (Frankfurt, Lang, 2006); B Zeller, Damages under the Conventions of Contracts for the International Sale of Goods (New York, Oceana, 2005).

2 CISG-AC Opinion No 6, Calculation of Damages under CISG Article 74, rapporteur Professor JY Gotanda, available at www.cisg-online.ch/cisg/docs/AC-opinion\%206.pdf (accessed 27 June 2007).

3 Of course, Art 82 ULIS was confined to cases where the contract has not been avoided; see H Stoll and G Gruber in P Schlechtriem and I Schwenzer (eds), Commentary on the UN Convention on the International Sale of Goods (CISG) (Oxford University Press, and edn, 2005) Art on the International Sale ' $\mathrm{Food}$ (CISG) (Oxford University Press, 2nd edn, Kommentar zu (Berlin, Sellier/de Gruyter, I3th edn, 2005) Art 74, para 6. 
but powerful.4 According to this provision, damages 'consist of a sum equal to the loss, including loss of profit, suffered . . . as a consequence of the breach'. It is unanimously held that the standard laid down in this article is designed to place the aggrieved party in as good a position as if the other party had properly performed the contract. 5 The essential basic concept is the principle of full compensation. Thus, the loss for which compensation is to be granted includes both the lost expectation of performance as well as losses incurred in reliance on performance. ${ }^{6}$

Whereas these basic principles remain undisputed, the details have become more and more controversial. This is due to several developments in domestic legal systems and uniform law projects, such as the UNIDROIT Principles of International Commercial Contracts (PICC) and the Principles of European Contract Law (PECL). For example, in the UK, the last 20 years have been characterised by a real upheaval in the law of damages; to mention but a few of the leading cases: Ruxley, 7 Blake ${ }^{8}$ and Farley. ${ }^{9}$ In Germany, the German Forum of Jurists (Deutscher Juristentag) - the most influential group for enhancing the development of legal policy-dedicated a whole session of its 2006 conference to $\mathrm{New}$ Perspectives in the Law of Damages' ${ }^{\text {ro }} \mathrm{On}$ an international level, both the UNIDROIT PICC and the PECL must be mentioned here. In the first place, both sets of rules are, in essence, based on the same principle as the CISG, namely the principle of full compensation. II However, they go beyond the wording of the CISG. They not only expressly provide that the

4 JO Honnold, Uniform Law for International Sales under the 1980 United Nations Convention, (The Hague, Kluwer International Law 3rd edn, 1999) para 403.

5 See Secretariat Commentary, 'Art 70, para 3' in Official Records 59; GH Treitel, 'Remedies for Breach of Contract' (Oxford, Clarendon Press, I989) 82; Honnold, above n 4, para 403 CISG-AC, above n 2, para I.I; Gotanda, above n I, 98 .

${ }^{6}$ See Case No 7 Ob 30I/oIt, I4 January 2002, Oberster Gerichtshof (Austria Supreme Court), available at http://cisgw 3. law.pace.edu/cases/020II 4a3.html (accessed 28 June 2007) Stoll and Gruber, above n 3, Art 74, paras 2 et seq; Magnus, above n 3, Art 74, para 6; P Hube in K Rebmann, FJ Säcker and R Rixecker (eds), Kommentar zum Bürgerlichen Gesetzbuch (Munich, Beck, 4th edn, 2004) Art 74, para r 8; D Saidov, 'Methods of Limiting Damages under the Vienna Convention on Contracts for the International Sale of Goods', (2002) I4 Pace International Law Review 307; cf W Witz in W Witz, HC Salger and M Lorenz (eds), International Einheitliches Kaufrecht: Praktiker-Kommentar und Vertragsgestaltung zum CISG (Heidelberg, Verlag Recht und Wirtschaft, 2000) Art 74, para I2.

7 Ruxley Electronics and Construction Ltd v Forsyth [1996] AC 344 (HL). For comment and analysis, see B Coote, 'Contract Damages, Ruxley, and the Performance Interest' (1997) 56 CLJ 537.

8 Attorney General v Blake [200I] I AC 268 (HL). For comment and analysis, see G Jones, 'Must the Party in Breach Account for Profits from his Breach of Contract' in I Schwenzer and Hager (eds) Festschrift für Peter Schlecbtriem zum 70. Geburtstag (Tübingen, Mohr Siebeck, 2003) 763 .

9 Farley $v$ Skinner [2002] 2 AC 732 (HL). For comment and analysis, see R Holmes, 'Mental Distress Damages for Breach of Contract' 35 (2004) Victoria University Wellington Law Review 699 et seq.

10 For a report on this session, see S Manner, 'Tagungsbericht, Abteilung Zivilrecht' [2007] uristen Zeitung 232.

11 Art 7.4.2(I) PICC; Art 9:502 PECL. term 'loss' includes non-pecuniary loss, ${ }^{\mathrm{X} 2}$ but they also provide guidelines as to when future loss is to be compensated for. ${ }^{\mathrm{I}} 3$ These developments give rise to and, at the same time, are part of a general discussion of the aims and tasks of the law of damages in a modern world. Whereas, up until a few years ago, the main focus was on a very narrow notion of compensation, recent developments indicate that different aspects are now gaining importance. The pure 'economic benefits' principle has yielded to the 'performance' principle; ${ }^{\mathrm{I} 4}$ issues of prevention and deterrence have emerged, demanding, among other things, disgorgement of profits from the breaching party or other punitive mechanisms. All of these issues are accentuated by other emerging developments of modern global sales law, such as the protection of human rights by private companies in all sectors of international trade. ${ }^{\mathrm{I}} \mathrm{s}$

These new challenges cannot go unnoticed when applying and interpreting the CISG. The CISG began as a great endeavour to harmonise international sales law and has achieved this aim to a large extent. ${ }^{16}$ If it does not respond to current demands and continues to focus on the state of discussion prevalent in the I970s (or, more accurately, the nineteenth century), it risks falling back into obscurity. The necessary adjustments will then be made by the concurrent application of domestic remedies to precisely those cases for which the CISG was originally designed. The battle for uniformity fought by the CISG would be lost.

Although the following remarks are based upon the status quo, we see it as our task to contribute to the necessary, cautious and moderate modernisation of the CISG provisions on damages.

\section{II 'ECONOMIC BENEFITS' PRINCIPLE V 'PERFORMANCE'} PRINCIPLE

Although everybody seems to talk about the principle of full compensation, its precise meaning is far from clear. Full compensation or compensation for pecuniary loss is usually limited to the 'economic benefits' principle or, as it is called under Germanic legal systems, the

12 Art 7.4.2(2) PICC; Art 9:50I(2)(a) PECL.

13 Art 7.4.3 PICC. Art 9:50I PECL Comment F

13 Art 7.4.3 PICC; Art 9:50I PECL

15 See I Schwenzer and B Leisinger, 'Ethical Values and International Sales Contracts' in R Cranston et al (eds), Commercial Law Challenges in the $2 I^{\text {st }}$ Century, Jan Hellner in Memoriam Cranston et al (eds), Commercial Law Challenges in the 21 Century, Jan Hellner in Memoriam (Oxford University Press, 3 rd edn, 2003) I6 (in the context of English law). 16 16 For a list of member states, see www.uncitral.org/uncitral/en/uncitral_texts/sale_goods/ I980CISG.html (accessed 27 June 2007). Until now the CISG has entered into force in 70 states. decisions and arbitral awards rendered are published. 
'difference theory'. ${ }^{17}$ All other losses of the aggrieved party that do not directly appear on the balance sheet are simply deemed to be non-pecuniary and thus not compensable. The only acknowledged exception to this principle is found in Article 76 CISG, which allows the aggrieved party to calculate its damages for the loss in the value of the goods according to the current price on an abstract level, regardless of whether it has actually undertaken any cover transaction or not. ${ }^{18}$ The consequences of this strict interpretation of pecuniary loss may be best illustrated by three hypotheticals.

Hypothetical I: Suppose that the buyer is a commercial carrier buying ro trucks for transportation. If they are not delivered in time, it rents substitute trucks to carry on its business. Rental costs will unanimously be recognised as pecuniary loss under the economic benefits principle. However, let us change the facts slightly. The buyer is no longer a professional carrier but a non-governmental organisation (NGO) transporting food to the Sahel. As no substitute trucks can be rented where they are needed, no loss in this sense occurs.

Hypothetical 2: Suppose that a Swiss company, conscious of human rights, buys T-shirts from a seller in India on the contractual condition that no children are to be employed in manufacturing the goods. The buyer is willing to pay a price I00\% higher than the market price to ensure that such basic human rights are complied with. If the seller breaches the contract by employing children, this fact does not fundamentally change the tangible properties of the goods. If the buyer resells the goods without anybody becoming aware of the breach of contract, its revenues will be the same as if the seller had complied with the terms of the contract. Thus, in the strict sense, no pecuniary loss could be ascertained.

Hypothetical $3:^{\text {I9 }}$ Imagine that a professional photographer buys a Ferrari in a flashy pink colour, paying extra for this special paintwork for photo shootings. The Ferrari is delivered in ordinary standard red. As nobody else would buy a flashy pink Ferrari, the resale price of a standard red one is even higher than that of the car bargained for. Does this mean that the photographer has suffered no loss and cannot claim damages?

The majority view that no damages are to be awarded in such cases because of the absence of pecuniary loss is not convincing. If one confines damages to the economic loss caused by the non-performance, one ignores the fact that the aggrieved party has paid the price precisely to obtain the correct performance of the contract. This is, indeed, a pecuniary loss and not just a

17 See I Schwenzer, Schweizerisches Obligationenrecht Allgemeiner Teil (Bern, Stämpfli, 4th edn, 2006), para 14.03 .

18 See Honnold, above n 4, 4I 4; Stoll and Gruber, above n 3, Art 76, para I; Huber, above n 6, Art 76 , para $x$; Brölsch, above $\mathrm{n} x, 92$ et seq.

19 This case is comparable to the well-known case Ruxley, above n 7 . non-pecuniary loss. It is precisely this notion that distinguishes contractual damages from tortious damages. There can be no doubt that the scope of losses to be compensated for has to reflect the very purpose of the duty that has been breached. It may be conceded that duties arising in tort primarily protect integrity and against economic losses resulting directly from infringements of these duties. Contractual duties, on the other hand, aim at securing performance. ${ }^{20}$ The creditor must receive what it has bargained and paid a price for.

A further argument advanced in favour of the economic benefit approach, namely that any damages for losses that cannot be qualified as pecuniary losses in the traditional sense yield a windfall profit to the aggrieved party, ${ }^{2 I}$ can easily be discarded as well. Even if it were assumed that, according to the pure balance sheet such a windfall profit arises, the question has, to be asked as to who is to get the windfall profit if one denies damages for the aggrieved party. Should the breaching party in our hypotheticals really get off scot-free because it contracted with an NGO instead of a professional carrier; because the breach was never made public; or because the common Ferrari buyer prefers standard red over the extravagant flashy pink? The answer is a clear 'no'. This solution is further underscored by the necessity to prevent breaches of contract. If damages in these cases were to be denied, all the breaching party would have to face would be the avoidance of the contract, which presupposes a fundamental breach, thus merely depriving it of the purchase price. If there is no fundamental breach (Article 25 CISG), in some cases-as in the Ferrari hypothetical, where the resale price of the flashy pink Ferrari is lower than that of the standard red one-even a reduction of the price (Article 50 CISG) would fail. This follows from the majority view that the potential resale price is decisive not only for the remedy of damages, but also for the reduction of the purchase price. ${ }^{22}$

Ultimately, the possibility to contract for a penalty and thus recover, notwithstanding the fact that no pecuniary losses in the narrow sense can be ascertained, does not solve the problem in the cases discussed here. First, it is a circular argument as often the otherwise applicable domestic law requires there to be a pecuniary loss under the CISG for the validity of the penalty clause. Secondly, the aggrieved party may not always be in the economic position to bargain for a penalty.

Admittedly, the solution of awarding damages in the aforesaid cases does not, in principle, solve the crucial question of how to calculate these

20 See Coote, above $\mathrm{n} 7,540,566$.

21 On this issue, see Coote, $i b i d, 548$ et seq.

22 See M Müller-Chen, in Schlechtriem and Schwenzer, above n 3, Art 50, paras 8, 9; Magnus, above $\mathrm{n} 3$, Art 50, para 20; Honnold, above n 4, para $3 \mathrm{I}_{2} ; \mathrm{H}$ Salger in Witz et al, above $\mathrm{n} 6$, Art 50, para 3; F Enderlein, D Maskow and H Strohbach, Internationales Kaufrecht (Berlin, Haufe, I99I) Art 50, para 5. 
damages. Still, even though the calculation of damages may be much more difficult than in clear-cut cases, it is still possible. In cases of loss of use (hypothetical I), damages may be calculated by reference to a hypothetical market for the goods involved. For goods generally subject to the CISG, such a hypothetical market will usually be available. Nowadays, there is a rental market for almost everything; one may even rent a tank for warfare! And this holds true not only for fungible goods-one may also rent a Picasso painting for an exhibition. Thus, just as calculating damages for loss in value in relation to a market price is possible under Article 76 CISG, loss of use may be calculated by the same method of referring to a market price and rental market under Article 74 CISG.

If the focus is shifted from the economic consequences of non-performance to the 'performance' principle, there is also an easy way to calculate these damages in hypotheticals 2 and 3 . If the buyer pays twice as high a price to have T-shirts manufactured without child labour, the minimum loss it sustains is half of the purchase price, as this represents its interest in the correct performance. Usually this calculation can also be done by referring to the relevant markets. Today there are markets for products manufactured under any-including inhumane-conditions, as opposed to markets for products produced in compliance with basic human rights, or products that are fairly traded.

Likewise, the Ferrari hypothetical can be solved. Damages consist of the difference between a Ferrari with standard red painting and the costs necessary for flashy pink paintwork. This hypothetical raises another question: may the buyer in this case calculate its damages according to the costs of corrective paintwork? If the buyer has, indeed, had the colour changed and ensued corresponding costs which appear on the balance sheet, there can be no doubt that this is a possible basis of calculation. However, if the buyer resigns itself to the standard red colour, is it then prevented from claiming damages in the amount of the potential repair costs? Again, if the buyer refrains from actual repair, it cannot be to the benefit of the breaching seller. The seller owes performance in any case; it is up to the buyer to decide whether or not it uses the damages obtained for actual repairs. The necessary protection of the seller can be achieved through the mitigation principle laid down in Article 77 CISG. If the repair costs are grossly excessive compared with the interest a reasonable buyer would have in the strict performance of the contract, the buyer would breach its duty to mitigate losses if it were to claim these costs as damages for non-performance. ${ }^{23}$ This duty to mitigate, however, applies regardless of whether the buyer chooses to have the goods repaired or not.

${ }^{23}$ See I Schwenzer and S Manner, 'The Pot Calling the Kettle Black: The Impact of the Non-Breaching Party's (Non-)Behavior on its CISG-Remedies' in UG Schroeter and C Baasch-Andersen (eds) Festschrift for Albert H Kritzer (London, 2008); Stoll and Gruber, above n 3 , Art 77, para 9

\section{LOSS OF PROFIT AND LOSS OF REPUTATION}

\section{A Loss of Profit and Loss of Reputation as Pecuniary Losses}

Within the different losses possible, Article 74 CISG emphasises the loss of profit. The word 'loss' alone might be read narrowly to refer to out-of-pocket reliance expenses, but the mention of 'loss of profit' makes it clear that this is not what was intended. ${ }^{24}$ If, at the time of the decision of the court or tribunal, no further losses are to be expected, the calculation of loss of profit usually causes no further problems. Thus, if the buyer repudiates the contract, the seller's lost profit equals the purchase price minus the costs incurred by the seller. Today, it is also unanimously held that this' loss of profit can also be claimed in the so-called 'lost volume' cases. Such a lost volume situation arises when the seller has more goods in stock than it needs to serve its contracts, thus losing the profit on an additional transaction it could have carried out had the contract been performed. ${ }^{25}$ If the seller does not deliver the goods and the buyer is thus unable to fulfil contracts with its customers, the loss of profit consists of the resale price minus certain costs. However, there is no agreement as to which costs are to be deducted. ${ }^{26}$

Special problems arise in today's international sales in connection with corporate groups where, typically for tax purposes, the contractual partner is a domestic subsidiary, but the loss may be-at least ultimatelysustained by the parent company. In those legal systems that do not recognise undisclosed agency and thus do not give the principal a contractual right of recovery of its own, there can be no doubt that such a shift of loss cannot free the obligor from liability. ${ }^{27}$ The contractual partner may liquidate the loss sustained by the parent company.

Difficult problems arise where damages for future losses are claimed Whereas Article 9:50I(2)(b) PECL as well as Article 7.4.3(I) PICC allow for the recovery of future losses, Article 74 CISG does not expressly state that such losses may be recovered. However, the principle of full compensation certainly demands recovery in these cases, subject to the principles of foreseeability and mitigation. How to prove future losses is another question that will be discussed later.

Closely connected to the question of loss of profit is the concept of loss of a chance. ${ }^{28}$ Suppose that the famous architects Herzog \& de Meuron

24 EA Farnsworth, 'Damages and Specific Relief' (1979) 27 American Journal of Contract Law 249.

25 For the discussion of lost volume cases under the CISG, see Stoll and Gruber, above n 3 , Art 75 , para II; Saidov, above n 6, I.2(c); Brölsch, above n I, 87 et seq.

26 See CISG-AC, above n 2, 3.Io.

27 But see Stoll and Gruber, above n 3, Art 74, para 26.

28 See CISG-AC, above n 2, 3.I 5; Saidov, 'Standards', above n I, 39 et seq; Saidov, 'Damages', above $\mathrm{n}$ I, 400 et seq. 
are bidding for the erection of the Olympic stadium in Beijing. As they depend on the delivery of certain goods to finish their bid and the seller fails to deliver in time, they miss the deadline for entering the competition. May they claim damages for the loss of a chance to win the competition? Some authors strictly deny the recoverability of this loss. ${ }^{29}$ Yet, there can be no question that such chances have an economic value in the light of the significant sums of money invested in biddings. To give just one example: in Germany the German Football Association (Deutscher Fussballbund) invested around $€$ Io million in bidding for hosting the 2006 FIFA World Championship. The only difference between the 'loss of chance' and the traditional 'loss of profit' is the level of certainty with which it can be proven. Therefore, the wording 'loss of profit' in Article 74 CISG naturally encompasses the recovery of 'loss of a chance'.

Similar problems arise in connection with 'loss of goodwill' or 'damage to reputation'. Again, there can be no doubt that they do have an economic value having regard to the sums spent to enhance reputation in the market. ${ }^{\circ}$ Therefore, the principle of full compensation demands recovery of losses in this respect.

\section{B Burden and Standard of Proof}

As already mentioned, the crucial question surrounding 'loss of profit' is not whether the aforesaid losses are recoverable in principle, but rather what standard of proof is necessary for recovery.

\section{(i) Proof as a Matter Governed by the Convention}

There has been controversy surrounding the issue of whether questions of proof are a procedural matter to be resolved in accordance with domestic law or whether they are implicitly regulated by the CISG. ${ }^{\text {I }}$ Whereas currently the clear prevailing opinion regards the burden of proof as a matter governed by the Convention, ${ }^{32}$ courts and commentators have

29 Stoll and Gruber, above n 3, Art 74, para 22; K Neumayer and C Ming, Convention de Vienne sur les contrats de vente international de merchandises, Commentaire (Lausanne, CEDIDAC, x993) Art 74, para I. See also Delchi Carrier SpA $v$ Rotorex Corp, 6 December 1995, US Circuit Court of Appeals (2d Cir), available at http://cisgw3.law.pace.edu/cases/ 95 I206ux.html (accessed 28 June 2007).

30 Cf P Schlechtriem, Internationales UN-Kaufrecht (Tübingen, Mohr, 4th edn, 2007) para 299.

31 See CISG-AC, above n 2, 2.I et seq.

32 CISG-AC, above n 2, 2.I; C Brunner, UN-Kaufrecht-CISG. Kommentar zum Übereinkommen der Vereinten Nationenüber Verträge über den internationalen Warenkauf von I 980 (Bern, Stämpfli, 2004) Art 74, Rn 58; Huber, above n 6, Art 74, para 58; Magnus, above rejected the notion that the standard of proof is also governed by the Convention, as these questions were qualified as being procedural.33 Yet, the mere qualification of these rules as procedural or substantive cannot be the decisive factor. 34 The principle of full compensation constitutes the core of all damages provisions of the CISG. Allowing different domestic rules on the level of proof would undermine not only the uniform interpretation of the CISG norms, but the core principle of full compensation itself.

\section{(ii) Standard of Proof}

With respect to the required standard, it is now widely held that a standard derived from the notion of reasonableness should be applied. Such reasonableness is, for example, laid down in Article 9:502(2)(b) PECL, as well as in Article 7.4.3(I) PICC; reasonableness is also a standard used by various CISG provisions themselves. 35 The aggrieved party has to prove with reasonable certainty both the fact and the extent of loss. However, mathematical precision cannot be required. The aggrieved party must only provide a basis on which a court or tribunal can reasonably determine the extent of damages, be it by expert testimony, economic and financial data, market surveys and analysis, or business records of similar enterprises. ${ }^{36}$ It is then up to the court or tribunal to exercise its discretion in estimating the loss sustained.

\section{Minimum Loss}

If no possibility at all exists to ascertain the actual loss, the expenditures the obligee made in expectation of performance must be taken as the minimum loss that must be compensated for. It is reasonable to assume that the

n 3, Art 74, para 62; Brölsch, above n I, 50; Saidov, 'Standards', above n I, 53 et seq. But see Case No C/I2709/200I, I 5 November 2002, Cour de Justice Genève (Appellate Court, Geneva, Switzerland) para 4, available at http://cisgw3.law.pace.edu/cases/o2 I II 5s June 2007). 33 For the United States see Delchi Carrier $S p A v$ Rotorex Corp, above n 29; for Switzerland,
see Case No T $17 \mathrm{I} / 95,20$ February 1997 , Bezirksgericht der Saane (Zivilgericht) (District Court, Saane) para 6.4, available at http://cisgw3.law.pace.edu/cases/970220sI.html (accessed 27 June 2007). See further Stoll and Gruber, above n 3, Art 74, para 53; Huber, above n 6, Art

74, para 57; Magnus, above n 3, Art 74, para 6I.
34 CISG-AC, above n 2, 2.5; Gotanda, above $\mathrm{n}$ I, rog et seq; CG Orlandi, 'Procedural Law Issues and Law Conventions' 5 (2000) Uniform Law Review 23, 24 et seq.

35 See Arts 8(2) and (3), 25, 35(I)(b),60,72(2),75,77, 79(I), 85, 86 and 88(2); for 'reasonable time', see Arts $\mathrm{x} 8(2), 33(3), 39(\mathrm{I}), 43(\mathrm{I}), 47,49,63,64,65$ and $73(2)$. See also CISG-AC, above n 2, 2.6 et seq; Gotanda, above n I, I 26 et seq.

36 See CISG-AC, above n 2, 2.9. 
expenses incurred by a business person reflect what it may at the very least expect as payment. 37

\section{NON-PECUNIARY LOSSES}

As has been shown, many of the losses usually characterised as non-pecuniary are in fact pecuniary losses if the performance principle is relied upon. Therefore, the distinction between pecuniary and nonpecuniary losses, or material and immaterial losses, has to be established differently.

The only remaining losses that are traditionally considered as non-pecuniary are 'pain and suffering', 'mental distress' and 'loss of amenities'. Although Article 9:50I(2)(a) $\mathrm{PECL}^{38}$ and Article 7.4.2(2) PICC provide for the recovery of such losses in general, many of these losses already fall outside the scope of the Convention, since they flow from death or personal injury and therefore are already excluded by Article 5 CISG. But even where such losses are in no way connected to personal injury, for example, emotional distress following the simple non-delivery or diminished enjoyment of the goods because of a defect, they are still comparable to personal injuries as they constitute at least a psychological injury. They thus fall clearly outside the scope of the Convention. Furthermore, unlike travel agents who get paid for procurement of the enjoyment of holidays and who, consequently, may be liable to pay general damages for disappointment, ${ }^{39}$ parties to international sales contracts do not contract and pay for the enjoyment and the amenities of life.

\section{DISGORGMENT OF PROFITS AND GAIN-BASED DAMAGES}

As discussed extensively by other contributions in this collection, $4^{\circ}$ the last decade has seen many court decisions and much academic debate in connection with the disgorgement of profits derived from a breach of contract. This debate is closely linked to the discussion about the purposes and aims of the law of damages in general, namely the transition from pure

37 Schlechtriem, above n 29, para 308; N Schmidt-Ahrendts, 'Der Ersatz „frustrierter Aufwendungen “ im Fall der Rückabwicklung gescheiterter Verträge im UN-Kaufrecht' [2006] Internationales Handelsrecht 69.

38 Comment $\mathrm{E}$.

39 See Jarvis v Swan Tours [1973] 2 QB 233; Jacksonv Horizon Holidays [1975] I WLR I468 (United Kingdom); BGH, NJW I956, I234 and now $\$ 65$ I f BGB (Germany); Art I4 PauRG (Switzerland).

40 See A Burrows, 'Are "Damages on the Wrotham Park Basis" Compensatory, Restitutionary or Neither?', this volume; R Cunnington, 'The Measure and Availability of Gain-based Damages for Breach of Contract', this volume. compensation of economic loss to mechanisms of deterrence in order to strengthen the principle of pacta sunt servanda. It can be encapsulated by the following sentence: 'Breach of contract must not pay.' What stand does the CISG take on these developments? Except for the few authors who have laconically stated that under the CISG such disgorgement of profits may not be awarded, ${ }^{4 I}$ this question has yet to be addressed by the CISG community.

First of all, it has to be noted that cases comparable to the well-known Blake $^{42}$ case are hardly conceivable in an international sales context. However, in sales law the disgorgement of profits may play a role in the following cases: the seller who is already bound by the contract with the buyer sells the goods for a second time at a higher purchase price, realising a higher profit than that in the first contract. Can the buyer claim the revenue of the second sales contract? Another example would be the already-mentioned hypothetical in which the buyer contracts for goods manufactured without child labour. Can the buyer claim a sum equal to the amount that the seller saved in the production process by employing children instead of adults? Finally, consider the case that formed the basis for a decision by the Grenoble Court of Appeal (France). 43 Jeans were bought by the US buyer to be delivered to the buyer's customer in South Africa. The contract contained a provision prohibiting the buyer from selling the goods on the European market as the seller had exclusive contracts with its European customers. The buyer subsequently resold the goods on the European market. Can the seller ask for the proceeds of the sales undertaken in breach of the contractual duty? In these cases, the CISG should not prevent the aggrieved party from demanding the proceeds made by the other party in its breach of contract. Two reasons justify this.

First, in all these cases, the gains by the breaching party can easily be viewed as nothing more than a presumption of what the aggrieved party has actually lost. Thus, we are still in the realm of compensatory damages. In the first example, of the seller selling the same goods twice, the higher purchase price that the breaching seller was able to realise can be seen as an indication and proof of what the true market conditions must have been at the time of the breach. The performance interest of the buyer, who has the right to the goods, compels granting it this amount. The same holds true for the second hypothetical - the child labour case. As has been

41 Stoll and Gruber, above $\mathrm{n} 3$, Art 74, para $3 \mathrm{I}$; Huber, above n 6, Art 74, para $\mathrm{x}$ 6; Magnus, above n 3, Art 74, para 18; Brölsch, above n I, 44; H Honsell, 'Die Vertragsverletzung des Verkäufers nach dem Wiener Kaufrecht' [1992] Schweizerische Juristen-Zeitung 361. On the ULIS, see Adras Building Material v Harlow \& Jones GmbH, Supreme Court of Israel, 2 November 1988, (I995) 3 Restitution Law Review 235.

42 Attorney-General v Blake [200I] I AC 268 (HL)

43 SARL BRI Production "Bonaventure" v Société Pan African Export, 22 February 1995, CA Grenoble (Court of Appeal, Grenoble, France), available at http://cisgw3.law.pace.edu/ cases/950222fr.html (accessed 27 June 2007). 
shown, the buyer is entitled to damages for the lesser value of the goods, as it has paid a higher price for having them manufactured under humane conditions. If it is difficult or impossible to determine the diminished value of goods produced under inhumane conditions, the savings made by the seller can be taken as a valuable yardstick in calculating the minimum loss of the buyer. Finally, in the case of the reimported jeans, the gains by the reselling buyer made in violation of the contract terms can be viewed as an indication of the seller's lost profits. Thus, in all of these cases, the question is not one of disgorgement of benefits, but of calculation of damages in accordance with the principle of full compensation. The second reason why the CISG cannot simply negate the issue of disgorgement of profits and gain-based damages is that, otherwise, courts might resort to concurring domestic remedies in order to solve these currently virulent issues. Thereby, the CISG would be undermined in one of its core areas.

\section{PUNITIVE OR EXEMPLARY DAMAGES}

Punitive or exemplary damages is another area of the law that has been newly discovered by contract lawyers. Such damages are usually defined as sums awarded in excess of any compensatory or nominal damages in order to punish a party for outrageous misconduct. 44 Whereas jurists from the Germanic legal systems, in particular, have been and still are strictly opposed to any form of punitive damages, 45 more and more common lawyers tend to advocate the concept of punitive damages, not only in tort, but also in contract law. ${ }^{46}$

Under the CISG, it is generally held that punitive or exemplary damages may not be awarded 47 because Article 74 CISG limits damages to 'a sum equal to the loss, including loss of profit ... a as a consequence of the breach'. Even the CISG-AC has recently upheld this position in its 2006

44 For a comparative study, see JY Gotanda, 'Punitive Damages: A Comparative Analysis' (2004) 42 Columbia Journal of Transnational Law 39I.

45 BGH, 4 June I992, BGHZ xI8, 3 I2; F Bydlinski, 'Die Suche nach der Mitte als Daueraufgabe der Privatrechtswissenschaft' (2004) 204 Archiv für die Civilistische Praxis 309 , 344 et seq.

46 See R Cunnington, 'Should Punitive Damages be Part of the Judicial Arsenal in Contract Cases?' (2006) 26 Legal Studies 369 et seq; JA Sebert, 'Punitive and Nonpecuniary Damages in Actions Based upon Contract: Toward Achieving the Objective of Full Compensation' (I986) 33 University of California Los Angeles Law Review 1565 et seq.

47 Stoll and Gruber, above n 3, Art 74, para 3 I; Magnus, above n 3, Art 74, para 17 ; Huber above n 6, Art 74, para I 6; Brunner, above n 30 , Art 74, para I 8 ; Brölsch, above n I, 43; but se Kirby, 'Punitive Damages in Contract Actions: The Tensions Between the United Nations Convention on Contracts for the International Sale of Goods and U.S. Law' (1997) I6 Journal of Law and Commerce 2I5, 224 et seq. opinion on 'calculation of damages'. $4^{8}$ Nonetheless, however true this position might be from a dogmatic point of view, it overlooks the fact that, in practice, full compensation of the aggrieved party is hardly ever achieved, since all risks in awarding and assessing damages rest with the aggrieved party. It has been rightly pointed out that the aggrieved party is, structurally, left undercompensated.49 Thus, there is a strong argument that, at least in cases where the breach was intentional and in bad faith, punitive damages can serve primarily as a vehicle to assure that the aggrieved party achieves full compensation. $5^{\circ}$

It follows that, although under the CISG there may not be a possibility of an explicit punitive damages award, this should not preclude the court or tribunal from taking punitive elements into consideration when dealing with intentional and bad faith breaches of contract. This could not only influence the standard of proof to be applied but also the assessment of damages in the individual case, in which the court or the tribunal is usually given a wide discretion. This becomes especially important in cases of loss of profit, loss of a chance or loss of reputation.

\section{LEGAL COSTS}

Apart from the hitherto discussed fundamental questions of damages, there is one group of cases that has received a great deal of attention under Article 74 CISG lately: the recovery of expenses incurred in taking legal measures, in short, attorneys' fees. ${ }^{51}$ Article 74 CISG does not expressly address the recovery of legal costs by an aggrieved party in connection with seeking relief for breach of contract.

Again, as in the area of questions of proof, the controversy centres on the issue of whether the recovery of legal expenses is a procedural matter or a matter governed by the Convention's substantive provisions. Those in favour of the latter view, in particular, argue that Article 74 CISG must be broadly interpreted in light of the principle of full compensation; otherwise the aggrieved party would not be adequately recompensed..$^{2}$ Likewise, as

48 CISG-AC, above n 2, 9.5 .

49 Sebert, above $\mathrm{n} 44, \mathrm{I} 568$.

$50 \mathrm{Ibid}, \mathrm{I} 647$ et seq.

51 The dispute has been further fuelled by the decision in Zapata Hermanos Sucesores, SA Hearthside Baking Company, Inc d/bla Maurice Lenell Cooky Company, I9 November 2002 US Ct App (7th Cir), available at http://cisgw3.law.pace.edu/cases/o2 Ir.r gur.html (accessed 27 June 2007). For comment and analysis, see H Flechtner and J Lookofsky, 'Viva Zapatal American Procedure and CISG Substance in a U.S. Circuit Court of Appeal' (2003) 7 Vindobona Journal of International Commercial Law and Arbitration 93 et seq.

52 See B Zeller, 'Interpretation of Art 74-Zapata Hermanos $v$ Hearthside Baking-Where Next?' [2004] Nordic Journal of Commercial Law I; Zeller, above n I, I48 et seq; J Felemegas, 'The Award of Counsel's Fees Under Art 74 CISG, in Zapata Hermanos Sucesores $v$ Hearthside Baking Co.' (200I) 6 Vindobona Journal of International Commercial Law and Arbitration 30, 38 . 
has been outlined in connection with the standard of proof, the problem of recovery of litigation costs cannot be solved through a substance/procedural distinction. Relying on such a distinction is outdated and unproductive. ${ }^{53}$ Instead, the analysis should focus on the purposes of damages under the CISG.

The principle of full compensation, at first sight, seems to support the view that any expenses connected to the breach of contract, including legal costs, should be recoverable. However, such an interpretation is clearly against the principle of equality between buyer and seller. If legal expenses are awarded under Article 74 CISG, a successful claimant would be able to recover litigation expenses. But, as Justice Posner has rightly asked, 54 what if the respondent won? Several proposals allowing the successful respondent the recovery of legal fees have proven unconvincing. 55 Thus, the only solution nowadays favoured by courts and scholarly writings is that, under Article 74 CISG, neither party can recover expenses associated with the litigation arising from the breach..$^{6}$

Up until now, the focus has been on litigation costs. Despite the fact that, today, it is widely acknowledged that litigation costs may not be recovered under Article 74 CISG,57 the prevailing opinion in courts, tribunals and scholarly writings seem to hold that pre-litigation costs may be recovered as incidental damages under Article $74.5^{8}$ Undoubtedly, this is correct as far as costs for the mitigation of damages are concerned, for

53 See CISG-AC, above n 2, 5.2.

54 Zapata Hermanos Sucesores, above in 5 I.

55 It has been argued an unsuccessful claimant could be held liable for breach of the duty of good faith and therefore a successful respondent could rely on breach of contract, see J Felemegas, 'An Interpretation of Art 74 CISG by the U.S. Circuit Court of Appeals' (2003) I 5 Pace International Law Review $9 \mathrm{r}, \mathrm{r} 26$.

56 CISG-AC, above n 2, 5.Iff. See also A Mullis, 'Twenty-five Years On-The United Kingdom, Damages and the Vienna Sales Convention' (2007) 7I Rabels Zeitschrift für ausländisches und internationals Privatrecht 35, 44; Huber, above n 6, Art 74, para 43; Brunne above n 30, Art 74, Rn 31; Brölsch, above n I, 69; Stoll and Gruber, above n 3, Art 74, para 20 ; Magnus, above n 3, Art 74, para 52; but see China International Economic \& Trade Arbitration Commission (CIETAC), Award of I I February 2000, available at http://cisgw 3 .law.pace.edu/ cases/0002 IIcr.html (accessed 27 June 2007). Commentators further advance Judge Posner's argument that the United States would not have ratified the CISG, if this had led to abolishing the so-called 'American Rule' (see Flechtner and Lookofsky, above n 49, 93ff; Schlechtriem, 'Verfahrenskosten als Schaden unter UN-Kaufrecht' [2006] Internationales Handelsrecht 49 , $52)$.

57 See n 54 .

58 See Zapata Hermanos Sucesores, above n 51); Case No 22 O 38/06, I2 December 2006 LG Coburg (District Court, Coburg, Germany), available at http://cisgw3.law.pace.edu/cases 06I.2I2gr.html (accessed 27 June 2007); Case No I6 U r7/05, 3 April 2006, OLG Köln (Provincial Appellate Court, Köln, Germany), available at http://cisgw3.law.pace.edu/cases/ 060403gr.html (accessed 27 June 2007); Case No 32 O 508/04, to December 2004, LG Bayreuth (District Court, Bayreuth, Germany), available at http://cisgw3.law.pace.edu/cases/ 04 I 2IOgI. html (accessed 27 June 2007); Case No 6 U 2 Io/03, 22 July 2004, OLG Düsseldor (Provincial Appellate Court, Düsseldorf, Germany), available at http://cisgw3.law.pace.edu/ cases/040722gr.html (accessed 27 June 2007). See also Stoll and Gruber, above n 3, Art 74 para 20; Magnus, above $\mathrm{n}_{3}$, Art 74, para 52. example, for a cover transaction or costs for examining the goods twice after the delivery of substitute goods. There are, however, pre-litigation costs that are not neatly separated from these costs and that should not be recoverable as damages. These encompass especially the legal costs for the provisional assessment of the legal situation, of the possible outcome of any litigation and settlement negotiations. These costs may easily amount to hundreds of thousands of euros and, again, both parties incur these costs. Therefore, here, too, the above-stated principle of equality between the parties prohibits allowing a successful claimant to be able to liquidate these costs as damages under Article 74 CISG. Hence, not only expenses associated with litigation arising from the breach, but also those pre-litigation costs that are incurred in preparation for or instead of litigation have to fall outside of the scope of Article 74 CISG.

\section{SUMMARY}

In summary, in many areas, the CISG provisions on damages still reflect the discussions prevailing in the mid-twentieth century. As German authors and courts have been, and still are, at the forefront of interpreting the CISG, it comes as no great surprise that traditional notions of the German law on damages have exerted an important influence. They, in turn, are still deeply rooted in the nineteenth century. Under French law, courts have an extremely wide discretion in awarding damages. Thus, there has never been much fundamental discussion, in French court decisions, about the scope of the provisions on damages under the CISG either. Anglo-American courts and scholars have only recently discovered the CISG and there the debate is just starting. Aspiring to the idea that the CISG is to govern international sales transactions on a truly uniform basis, we have to apply and interpret its provisions in such a core area as damages in a truly comparative way. This implies that we observe the discussions and developments in domestic laws and that we try to keep up with changed and still changing demands made by the international globalised market. In the law of damages this requires a shift from the nineteenth-century dogma of pure economic benefit to the performance principle, which includes notions of disgorgement of gains and punitive elements. The consequences of such a shift affect all areas of damages: lesser value of the goods and loss of use, loss of profit, loss of a chance and loss of reputation. It is only in this way that the CISG can be prepared for the twenty-first century and all its demands of a truly modern international sales law. 